\title{
Potential Framework Species in Mt. Musuan, Bukidnon, Philippines
}

\author{
LOWELL G. ARIBAL \\ ORCID No. 0000-0002-8530-3267 \\ ariballowell@yahoo.com.ph \\ Department of Forest Biological Sciences \\ College of Forestry and Environmental Science \\ Central Mindanao University \\ ANNARICA M. BALENDEZ \\ ORCID No. 0000-0001-6973-6700 \\ annarie0889@gmail.com \\ College of Forestry and Environmental Science \\ ADRIAN M. TULOD \\ ORCID No. 0000-0001-9704-0567 \\ amtulod@gmail.com \\ Department of Forest Resources Management \\ College of Forestry and Environmental Science \\ Central Mindanao University
}

\begin{abstract}
The Philippines is among the severely deforested countries in the tropics and in Southeast Asia. Deforestation resulted to the massive loss of species including aggravated environmental-related disasters and calamities. Recent government program aimed to reforest degraded lands had been initiated through the "National Greening Program" thus the need to identify potential indigenous and endemic species to be used for forest restorationand/or reforestation was recognized. Using the "framework species approach" (FSA), this study was conducted to determine potential candidate species. Sampling method involves
\end{abstract}


rapid assessment thru a $1000 \mathrm{~m}$ transect walk and random establishment of six sampling plots measuring $10 \times 10 \mathrm{~m}^{2}$ within the successional forest and grassland community of Mt. Musuan. Potential candidate species was assessed mainly via quantitative measures (i.e. relative frequency and density) as this suggest the species' ability to colonize, inhabit and survive on degraded areas. A total of twenty-one tree species were identified to include: Wikstroemia lanceolata Merr., Ficus ampeles Burm.f., Wendlandia luzoniensis DC., Glochidion lutescens Blume, Glochidion album (=Phyllanthus albus (Blanco.) Muell.Arg.), Myrsine mindanaensis (Elmer) Pipoly, Cratoxylum sumatranum Jack (Blume), Cratoxylum formosum (Jacq.) Benth.\& Hook.f.ex Dyer, Rhus taitensis Guill., Neonauclea formicaria (Elmer) Merr., Neonauclea media (Havil.) Merr., Antidesma ghaesembilla Gaertn., Antidesma bunius (L.) Spreng., Polyscias nodosa (Blume) Seem., Gmelina elliptica Sm., Buchanania arborescens (Blume) Blume, Lepisanthes fruticosa (Roxb.) Leenh., Ficus pseudopalma Blanco, Crypteronia paniculata Blume, Vitex parviflora A. Juss. and Leucosyke capitellata Wedd.

Keywords: framework species, forest restoration, Mt. Musuan, successional forest

\section{INTRODUCTION}

Deforestation is a worsening scenario in the Philippines. Remaining forests have been constantly under threat as illegal logging, timber poaching, and shifting cultivation continue to aggravate due to increasing poverty and lack of sustainable livelihood opportunities. This resulted to widespread rapid land use change where much of the forestlands have been fragmented being replaced with agriculture and eventually abandoned as open marginal land. Despite the governments' imposition on log ban, deterring deforestation and forestland destruction proved to be impossible and conservation remains a tough challenge. Massive reforestation efforts had been initiated in the past, but unsubstantiated with concrete evidence of restored forest ecosystem. These failed reforestation efforts were primarily due to inappropriate choice of species and mostly associated with the use of fast-growing exotic species such as Gmelina arborea Roxb., Swietenia macrophylla King, Tectona grandis L.f. (Lasco and Pulhin 2006; Tolentino 2008) including Acacia mangium Willd. with timber production as the eventual purpose. Exotics were favoured over native or indigenous species 
mainly because of their perceived adaptability and tolerance to stress, to grow faster than native species, widely available germplasm, and better understood silvicultural requirements (Tolentino 2008). This reforestation was aimed only to replace the lost forest rather than to restore back the biodiversity and its inherent ecosystem services. However, if reforestation sites are to fulfil their statutory function of biodiversity conservation, then activities must consider the composition of the communities being re-constructed and ensure the full suite of species are restored at sites (Elliot et al. 2010; French 2010). Such restoration should aim to complement natural forest regeneration rather than to replace it (Elliot et al. 2003). According to French (2010), a critical aspect of a community structure is the presence of a full complement of species that naturally occur in the community or in nearby natural undisturbed communities. However, while it is impractical to plant all tree species that may once have been present, it is possible to restore the levels of tree species richness, ecosystem structure and ecological functioning, of the original forest ecosystem (Elliot et al. 2003).

Thus, in support of the recent government restoration program for degraded lands in the country, dubbed as the "National Greening Program or NGP", this study was conducted to highlight the importance of using 'framework species' in the restoration process and identify possible community structure for degraded grassland community. The 'framework species' method is a highly specialized form of reforestation which is gaining widespread recognition and was proven to be successful in Australia and Thailand (Goosem and Tucker 1995; Lamb et al. 1997; Tucker and Murphy 1997; Tucker 2000; cited by Elliot et al. 2003). It involves planting mixtures of 20-30 both pioneer and climax tree species in a single step (Elliot et al. 2003). Framework species are indigenous forest tree species, planted to complement and accelerate natural regeneration of forest ecosystems and encourage biodiversity recovery on degraded sites (Elliot et al 2003). It is known to accelerate biodiversity recovery, because the species chosen for planting are from original, remnant forest (Elliot and Kuaraksa 2008). The characteristics of framework species includes: high survival and growth rates in open degraded sites; spreading dense crowns that shade out herbaceous weeds; and provision of resources that attract seed-dispersing wildlife (e.g. fruits, nectar, nesting sites, etc.) at an early age (Goosem and Tucker 1995). In this paper, we emphasized the high survival and growth rate as the main criteria for selecting the framework species via quantitative measure (e.g. relative density and relative frequency) as this suggest the species' ability to colonize, inhabit and survive on degraded areas. No trial field plots were established, assessment was made 
directly in the recently formed successional forest and grassland ecosystems of Mt. Musuan.

\section{MATERIALS AND METHODS}

\section{Study Site}

The study was conducted in Mt. Musuan, Musuan, Maramag, Bukidnon with geographic coordinates of $7^{\circ} 52^{\prime} 36.02^{\prime \prime} \mathrm{N}$ and $125^{\circ} 04^{\prime} 1.53^{\prime \prime} \mathrm{E}$ (Figure 1). Mount Musuan or locally known as Musuan Peak has an elevation of $646 \mathrm{~m}$ above sea level and consists of various land uses. This magnificent landmark stands within the landholdings of Central Mindanao University and serve as the study sites of various forestry-related researches and studies. The northwest side is comprised of a natural forest covering approximately 272.60 hectares. The southeastern portion of Mt. Musuan is cultivated to sugarcane plantation. By way of elevation, Mt. Musuan can be subdivided into two (2) layers, the upper layer is a plantation forest of various fast-growing exotic species such as Pinus caribaea Morelet, Tectona grandis L.f., Senna siamea (Lam.) H.S. Irwin \& Barneby, and Swietenia macrophylla King initiated by the College of Forestry as a flagship afforestation initiative 20 years ago. Over the years, the improved microclimatic condition within the periphery of the plantation forest has allowed a successional forest to develop however large portion of the remaining area is colonized by grasses dominated by Imperata cylindrica (L.) Raeusch. Covering approximately 70 hectares, the successional forest and grassland community has moderate relief with slopes that ranges between $10 \%$ and $30 \%$. Neighboring informal settlers had continuously exploited this area through fuel wood harvesting and other unauthorized extraction activities. Continued afforestation and reforestation efforts were quite unsuccessful due to sporadic fire incidence and extremely poor site conditions. 


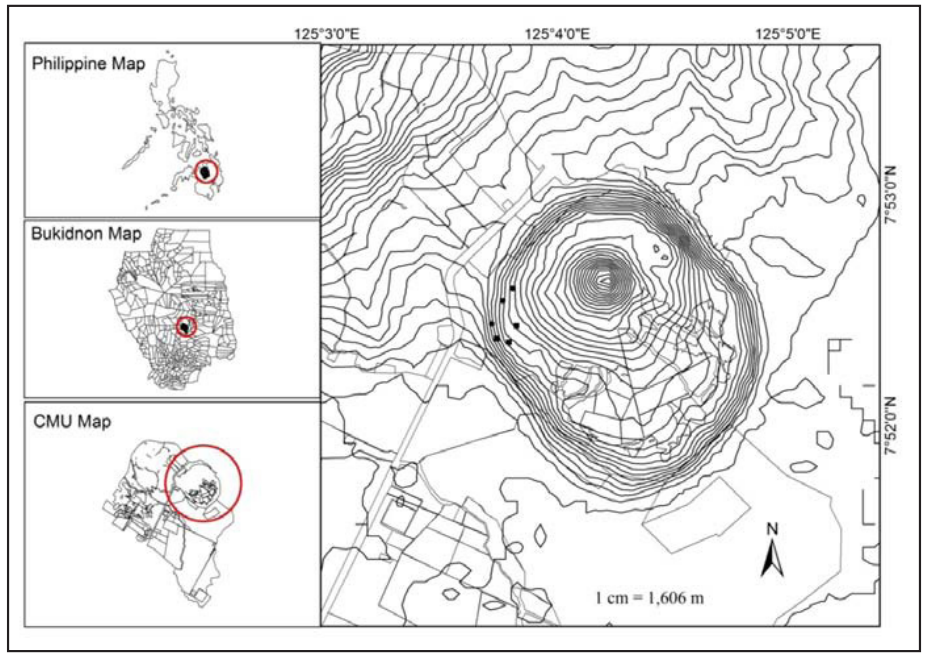

Figure 1. Study site and location of sampling points

\section{Soil Analyses}

Soil samples were collected at random within the delineated sampling points at a depth of $0-30 \mathrm{~cm}$. Twenty (20) sub-samples were collected on every plot. The collected sub-samples had been thoroughly mixed and a representative sample was taken for laboratory analyses to determine the following variables such as organic matter $(\mathrm{OM})$, nitrogen $(\mathrm{N})$, ammonium $\left(\mathrm{NH}_{4+}\right)$, phosphorous $(\mathrm{P})$, and potassium $(\mathrm{K})$, total carbon, and soil $\mathrm{pH}$.

\section{Tree Survey}

Tree inventory was conducted on the six $10 \times 10 \mathrm{~m}$ sampling plots delineated randomly within the successional forest and grassland community of Mt. Musuan. The spatial design of the plots was dependent to landscape configuration hence, plots were located and distributed using Google image taking consideration all the geographic coordinates of the location of each plot. All the plants within the plot with $\geq 5 \mathrm{~cm}$ at $\mathrm{dbh}$ were inventoried.

Moreover, to expand the list of the potential framework species, a rapid assessment was also conducted via transect walk to about 1000 meter within the study site. Voucher specimens were collected for the correct identification of species. The collection of specimens is covered by Wildlife Gratuitous Permit No. R102013-20 issued by the Department of Environment and Natural Resources, Region 10. 


\section{Identification of Potential Framework Species}

The modified species importance value (SIV) was used to determine the overall importance of each species in the community structure. This was determined by summing up the percentage values of the relative frequency and relative density. We intend not to include the relative dominance because of the assumption that both the relative frequency and relative density would determine the population of the most adapted species that had survived despite extreme conditions of water deficiency and insufficient nutrient availability thus, implying species' survival ability. The determination of importance value was computed following the formula by Mueller-Dombois and Ellenberg (1974) below:

Importance value $=$ relative frequency + relative density

\section{a. Relative Frequency}

Relative frequency is the degree of dispersion of individual species in an area in relation to the number of all the species occurred.

Relative Frequency $=\frac{\text { Number of occurrence of a species }}{\text { Number of occurrence of all the species }} \times 100$

Frequency $=\frac{\text { Number of plots where a species occur }}{\text { Total number of plots }}$

b. Relative Density

Relative density is the numerical strength of a species in relation to the total number of individuals of all the species. Relative density is determined by:

Relative Density $=\frac{\text { Number of individual of the species }}{\text { Number of individual of all the species }} \times 100$

Density $=\frac{\text { Total number of individuals of a species }}{\text { Total number of quadrats }}$ 


\section{RESULTS AND DISCUSSION}

\section{Soil chemical properties}

Owing to the proximity of the successional forest and grassland community in the study, it is not surprising that a slight difference in soil chemical properties was observed in these sites (Table 2). While successional forest indicated better soil condition numerically than the grassland community, both sites are marginal in condition with generally acidic soil and very low nitrogen, ammonium, available phosphorus, exchangeable potassium, and organic carbon content. The NPK content, for instance, is way below the minimum quantities (i.e. $1000 \mathrm{ppm}$ ) required by plants to sustain its normal functioning (Pallardy, 2008). In terms of $\mathrm{pH}$ condition, successional forest showed moderate to slightly acidic soil with $\mathrm{pH}$ level ranging from 5.91 to 6.14 ; while the grassland community is also generally slightly acidic ranging from 6.26 to 6.28 . This result does not corroborate the findings of Ramirez-Marcial et al. (2001) that changes of vegetation structure may alter or improve the soil $\mathrm{pH}$ condition. It is possible that the forest is at its early stage of succession thus the very low organic matter content observed in the soils and the expected sequential changes that are concurrent with vegetative seral stages are not yet fully in place. The vegetation cover can have fundamental effects on soil properties (Rutigliano et al. 2004; Singh et al. 2004), mainly due to its contribution towards inputting the amount of organic matter to soil by supplying carbon and energy sources from root exudates and plant remains. Organic matter plays a key role in supplying nutrients and water and provides good physical conditions to the plants (Bhat et al. 2011). Organic matter also is an indicator of the availability of nitrogen in the soil. The amount of soil organic matter represents the balance of primary productivity and decomposition and as such is a sensitive and integrated measure of change in ecosystem function (Burke et al. 1989). While a large percentage of the detritus forests is derived from litter and is rapidly mineralized on the forest floor, a major portion of grassland detritus is found deep within the soil (Jones 1973; Sanchez 1976; Kadeba 1978). Forbes et al. (2012) mentioned that most of the nitrogen in the soil is held in organic matter as organic nitrogen, a form that plants cannot use. Soil micro-organisms convert organic nitrogen into ammonium $\left(\mathrm{NH}_{4}\right)$ and nitrate $\left(\mathrm{NO}^{3-}\right)$.

Surprisingly, the soil organic carbon (SOC) in the successional forest was generally low as compared to grassland community. Potential explanation with the lower SOC is may be due to leaching from the upper to lower layers of soil horizon as well as vertical mixing by soil organisms. Changes in root tissue 
quality with depth caused by larger and woodier structures in deeper soil layers or lower nutrient concentrations, could also contribute to the observed pattern (Pregitzer $e$ t al. 1998, Gordon and Jackson 2000). Kamp et al. (2009) reported a higher carbon stock under grassland than under primary forest. Soil organic carbon (SOC) in grasslands and savannas represents one of the largest reservoirs of carbon on earth (Conant et al. 2001; Lal et al. 2007).

Table 2. Soil chemical properties of successional forest and grassland community

\begin{tabular}{|c|c|c|c|c|c|c|c|c|}
\hline \multirow[t]{2}{*}{ SITE } & \multirow{2}{*}{ Plot } & \multirow{2}{*}{$\begin{array}{c}\text { Total N } \\
(\%)\end{array}$} & \multirow{2}{*}{$\mathrm{NH}_{4}^{+}$} & \multirow[t]{2}{*}{$\mathrm{pH}$} & \multirow{2}{*}{$\begin{array}{l}\mathrm{OM} \\
(\%)\end{array}$} & \multirow{2}{*}{$\begin{array}{l}\mathrm{OC} \\
(\%)\end{array}$} & Available P & $\begin{array}{c}\text { Exchangeable } \\
\text { K }\end{array}$ \\
\hline & & & & & & & (ppm) & (ppm) \\
\hline \multirow{4}{*}{$\begin{array}{l}\text { Grassland } \\
\text { Community }\end{array}$} & 1 & 0.085 & 8.38 & 6.26 & 1.72 & 1 & 4.03 & 33 \\
\hline & 2 & 0.085 & 16.77 & 6.01 & 1.15 & 0.67 & 2.28 & 27 \\
\hline & 3 & 0.056 & 8.38 & 6.28 & 1.72 & 1 & 2.89 & 39 \\
\hline & Mean & 0.075 & 11.177 & 6.183 & 1.530 & 0.890 & 3.067 & 33.000 \\
\hline \multirow{4}{*}{$\begin{array}{l}\text { Successional } \\
\text { Forest }\end{array}$} & 1 & 0.085 & 16.77 & 5.91 & 1.92 & 1.12 & 2.09 & 33 \\
\hline & 2 & 0.056 & 16.77 & 6.14 & 0.96 & 0.56 & 6.26 & 36 \\
\hline & 3 & 0.099 & 25.15 & 5.85 & 1.92 & 1.12 & 8.26 & 33 \\
\hline & & 0.080 & 19.563 & 5.967 & 1.600 & 0.933 & 5.537 & 34.000 \\
\hline
\end{tabular}

\section{Potential Framework Species}

The rapid assessment thru a 1000 meter transect walk had identified at least 14 potential framework species. The species include the following however, does not imply any order of quantitative significance such as: Wikstroemia lanceolata Merr.,Cratoxylum formosum (Jacq.) Benth.\&Hook.f. ex Dyer, Rhus taitensisGuill., Neonauclea formicaria (Elmer) Merr., Wendlandia luzoniensis DC., Polyscias nodosa (Blume) Seem., Gmelina elliptica Sm., Glochidion album (= Phyllanthus albus (Blanco) Müll.Arg.), Cratoxylum sumatranum Jack (Blume), Antidesma ghaesembilla Gaertn., Buchanania arborescens (Blume) Blume, Lepisanthes fruticosa(Roxb.) Leenh., Myrsine mindanaensis (Elmer) Pipoly, Ficus pseudopalma Blume, Antidesma bunius (L.) Spreng.,and Crypteronia paniculata Blume. Within the sampling plots of the successional forest, three (3) species had the highest species importance value (SIV), this includes: Wikstroemia lanceolata Merr. (30.60\%), Ficus ampeles Burm.f.(29.56\%) and Wendlandia luzoniensis DC.(22.49\%).This was followed by Glochidion lutescens Blume(19.73\%), 
Myrsine mindanaensis (Elmer) Pipoly(17.21\%), and Cratoxylum sumatranum Jack (Blume) (16.74\%) (Table 1). In the grassland community, Wikstroemia lanceolata Merr.was the most abundant species. Other species recorded includes: Antidesma ghaesembilla Gaertn., Neonauclea formicaria (Elmer) Merr., Rhus taetensis Guill. and Vitex parviflora A.Juss.

In summary, a total of 21 species were identified as potential framework species within the successional forest and grassland community majority of these species were pioneers. Four (4) species were observed to be consistently found in both sites. This includes W. lanceolata, A. ghaesembilla, N. formicaria and $R$. taetensis. Elliot et al. (2003) reported at least 37 framework species in northern Thailand with similarities to some of the genera we observed however differ in the number of identified species. Common genera includes: Gmelina, Rhus, Ficus, and Glochidion. This may suggest that the species under these taxa could be potentially used for forest restoration not only in the Philippines but may be throughout the Malesian region. For instance, Gmelina elliptica Sm., a species that grows well in open degraded areas could be a counterpart to Gmelina arborea Roxb. which was classified as "excellent" framework species in Thailand. Moreover, Rhus taetensis Guill exhibited a wide range of tolerance to various site conditions. Such species is also found associated with Caldcluvia, Acer, Syzygium, Aporosa in the tropical lowland evergreen rainforest formations of Balinsasayaw Twin Lakes Natural Park in Negros Occidental at elevations 800 to 1000 masl. $R$. taetensis along with W. luzoniensis also dominates in the nitosols soils of the degraded areas and environs of Mt. Kiamo in Malaybalay, Bukidnon, as well as in the calcareous soils of the remnant forest of the Municipality of Sumilao, Bukidnon (pers. obs.). However, no indigenous leguminous species was identified in this study, while Elliot et al. (2003) reported two species such as Erythrina stricta Roxb. and E. subumbrans (Hassk.) Merr. in Thailand. Osman et al. (2009) stressed that leguminous trees are excellent pioneer species because of their ability to enrich sterile soil by fixing nitrogen where soils are deficient in nutrients.

Table 1. Quantitative measure of species in the successional forest

\begin{tabular}{|l|l|c|c|c|c|}
\hline SPECIES & FAMILY & $\begin{array}{c}\text { NO. OF } \\
\text { INDIVIDU- } \\
\text { ALS }\end{array}$ & $\begin{array}{c}\text { RELATIVE } \\
\text { DENSITY } \\
(\%)\end{array}$ & $\begin{array}{c}\text { RELATIVE } \\
\text { FREQUENCY } \\
(\%)\end{array}$ & $\begin{array}{c}\text { IMPORTANCE } \\
\text { VALUE (\%) }\end{array}$ \\
\hline Wikstroemia lanceolata & Thymelaeaceae & 207 & 29.2 & 1.5 & 30.60 \\
\hline Ficus ampeles & Moraceae & 7 & 1.0 & 28.6 & 29.56 \\
\hline Wendlandia luzoniensis & Rubiaceae & 145 & 20.4 & 2.1 & 22.49 \\
\hline
\end{tabular}




\begin{tabular}{|l|l|l|l|c|c|}
\hline Glochidion lutescens & Phyllanthaceae & 11 & 1.6 & 18.2 & 19.73 \\
\hline Myrsine mindanaensis & Primulaceae & 13 & 1.8 & 15.4 & 17.21 \\
\hline Cratoxylum sumatranum & Hypericaceae & 22 & 3.1 & 13.6 & 16.74 \\
\hline Cratoxylum formosum & Hypericaceae & 87 & 12.3 & 3.5 & 15.70 \\
\hline Glochidion album & Phyllanthaceae & 7 & 1.0 & 14.3 & 15.28 \\
\hline Neonauclea formicaria & Rubiaceae & 70 & 9.9 & 4.3 & 14.15 \\
\hline Rhus taitensis & Anacardiaceae & 60 & 8.5 & 5.0 & 13.45 \\
\hline Neonauclea media & Rubiaceae & 3 & 0.4 & 6.7 & 7.09 \\
\hline Antidesma bunius & Phyllanthaceae & 6 & 0.9 & 5.0 & 5.85 \\
\hline Lepisanthes fruticosa & Sapindaceae & 2 & 0.3 & 5.0 & 5.28 \\
\hline Fagraea racemosa & Gentianaceae & 2 & 0.3 & 5.0 & 5.28 \\
\hline Leucosyke capitellata & Urticaceae & 10 & 1.4 & 3.0 & 4.41 \\
\hline Vitex parviflora & Lamiaceae & 3 & 0.4 & 3.3 & 3.75 \\
\hline Buchanania arborescens & Anacardiaceae & 3 & 0.4 & 3.3 & 3.75 \\
\hline Crypteronia paniculata & Crypteroniaceae & 3 & 0.4 & 3.3 & 3.75 \\
\hline Polyscias nodosa & Araliaceae & 4 & 0.6 & 2.5 & 3.06 \\
\hline
\end{tabular}

\section{Potential attractiveness to wildlife}

Most tree species take at least 2 years to produce flowers and/or fruits which likely to attract wildlife (Elliot et al. 2003), thus it was not possible within the duration of the study to assess its wildlife attractiveness.

\begin{tabular}{|l|l|l|l|}
\hline SPECIES & \multicolumn{1}{|c|}{ FAMILY } & & \\
\hline Wikstroemia lanceolata & Thymelaeaceae & Fruits & Birds \\
\hline Ficus ampeles & Moraceae & Fruits & Birds \\
\hline Wendlandia luzoniensis & Rubiaceae & & \\
\hline Glochidion lutescens & Phyllanthaceae & fruits & Birds \\
\hline Myrsine mindanaensis & Primulaceae & fruits & Birds \\
\hline Cratoxylum sumatranum & Hypericaceae & fruits & Birds \\
\hline Cratoxylum formosum & Hypericaceae & fruits & Birds \\
\hline Glochidion album & Phyllanthaceae & fruits & Birds \\
\hline Neonauclea formicaria & Rubiaceae & fruits & Birds \\
\hline Rhus taitensis & Anacardiaceae & fruits & Birds \\
\hline Neonauclea media & Rubiaceae & seeds & Birds/ants \\
\hline
\end{tabular}




\begin{tabular}{|l|l|l|l|}
\hline Antidesma bunius & Phyllanthaceae & fruits & Birds \\
\hline Lepisanthes fruticosa & Sapindaceae & fruits & Birds \\
\hline Fagraea racemosa & Gentianaceae & & \\
\hline Leucosyke capitellata & Urticaceae & & \\
\hline Vitex parviflora & Lamiaceae & fruits & Birds \\
\hline Buchanania arborescens & Anacardiaceae & fruits & Birds \\
\hline Crypteronia paniculata & Crypteroniaceae & & \\
\hline Polyscias nodosa & Araliaceae & fruits & Birds \\
\hline
\end{tabular}

\section{CONCLUSIONS}

The findings we observed depicts the impact of indigenous species in the overall modification of soil chemical properties as manifested by much better values in terms of nitrogen, phosphorus, potassium, $\mathrm{OM}$, among others in the successional forest compared to the grassland community based on soil analyses results. The modification of site conditions into a more favorable would enable for species recruitment. The potential framework species we mentioned here exhibited the ability to restore degraded areas by hastening natural succession. This also shows that indigenous species could survive and colonized poor sites contrary to existing perception that only the exotic fast-growing species can do the job. Similarly, Schneider et al. (2013) concluded that indigenous species such as Melia dubia Cav.(=Melia azedarach L.) and Terminalia microcarpa Decne. are excellent species for forest restoration including Shorea guiso Blume, S. contorta Vidal and Parashorea malaanonan Merr., which previously thought (especially the dipterocarp species) could not survive or perform poorly when planted in the open and degraded areas (Tolentino 2008).

Despite this very preliminary assessment, we recommend that field trials with the species should be conducted to further evaluate their performance and classify them following the criteria used by Elliot et al. (2003) to determine the species category such as excellent, acceptable, marginal, and unacceptable and rejected.

\section{LITERATURE CITED}

Bhat, H.S., A.B. Darzi, M.S. Dar, M.M. Ganaie And S.H. Bakhshi.

2001 Correlation of soil Physico-chemical factors with VAM fungi distribution under different agroecologicalconditions. International 
Journal of Pharma and Bio Sciences (2)2: B98 - B107.

Burke, I., C. Yonker, W. Parton, C. Cole, K. Flach and D. Schimel.

1989 Soil organic matter recovery in semiarid grasslands: Implications for the conservation reserve program. Ecological Applications 5(3): 793 - 801.

Conant, R. T., K. Paustian and E. T. Elliott.

2001 Grassland management and conversion into grassland: effects on soil carbon. Ecological Applications, 11:343 - 355.

Elliot, S., P. Navakitbumrung, C. Kuarak, S. Zangkum, V. Anusarnsunthorn, D. Blakesley.

2003 Selecting framework tree species for restoring seasonally dry tropical forests in northern Thailand based on field performance. Journal of Forest Ecology and Management 184 (2003) 177 - 191.

Elliot, S. and C. Kuaraksa.

2008 Producing Framework Tree Species for Restoring Forest Ecosystem in Northern Thailand. Springer.Small-scale Forestry.DOI 10.1007/ s11842-008-9070-2.

Forbes, M. G., K.L.Dickson, F.Saleh, W.T.Waller, R.D.Doyle, and P.Hudak.

2012 Recovery and Fractionation of Phosphorus Retained by Lightweight Expanded Shale and Masonry Sand Used as Media in Subsurface Flow Treatment Wetlands. Journal of Environmental Science \& Technology 39: 4621-4627.

Gordon, W. S. and R. B. Jackson.

2000 Nutrient concentrations in fine roots. Ecology 81:275-280.

Goosem, S.P and N.I.J. Tucker.

1995 Repairing the Rainforest - Theory and Practice of Rainforest Reestablishment in North Queensland's Wet Tropics. Wet Tropics Management Authority. Cairns.

Jones, M. J.

1973 The organic matter content of the savanna soils of West Africa. Journal of Soil Science 24: $42-53$. 
Kadeba, O.

1978 Organic matter status of some savanna soils of Northern Nigeria. Journal of Soil Science 125: 122 - 127.

Kamp, J. V. D., I. Yassir, and P. Buurman.

2009 Soil carbon changes upon secondary succession in Imperata grasslands (East Kalimantan, Indonesia). Geoderma 149: 76 - 83.

Lal, R., R.F. Follett, B.A Stewart and J.M. Kimble.2007. Soil carbon sequestration to mitigate climate change and advance food security. Soil Science 172, 943-956.

Lamb, D., J. Parrotta., R. Keenan, and N.I.J. Tucker.

1997 Re-joining habitat remnants: restoring degraded rainforest lands. In: Laurence, W.F., Bierrgaard Jr., R.O. (Eds.), Tropical Forest Remnants: Ecology, Management and Conservation of Fragmented Communities. University of Chicago Press, Chicago, IL.pp $366-385$.

Lasco, R.D. and J.M. Pulhin.

2006 Environmental impacts of community-based forest management in the Philippines. International Journal of Environmental Sustainable Development 5: $46-56$.

Lu, D., P. Mausel and E. Moran.

2002 Linking Amazonian secondary succession succession minous n. crossing opical Grasslands (Savannas). forest growth to soil properties. Wiley InterscienceNo. 02

Mueller-Dombois, D. and H. Ellenberg.

1974 Aims and Methods of Vegetation Ecology. John Wiley \& Sons. 547pp.

Osman, N., F.H. Ali, and S.S. Barakbah.

2009 The Role of Pioneer Vegetations in Accelerating The Process of Natural Succession. Institute of Biological Sciences, University of Malaya, 50603 Kuala Lumpur American Journal of Environmental Sciences 5 (1): 7-15, 2009ISSN 1553-345X@ 2009 Science Publication 
Pregitzer, K. S., M. J. Laskowski, A. J.Burton, V. C. Lessard and D. R.Zak. 1998 Variation in sugar maple root respiration with root diameter and soil depth. Tree Physiology 18: 665-670.

Ramírez-Marcial, N., M.González-Espinosa, and G.Williams-Linera.

2001 Anthropogenic disturbance and tree diversity in montane rainforests in Chiapas, Mexico. Forest Ecology and Management154: 311-326.

Rutigliano, F.A., R. D’ascoli, and A.Virzo De Santo.

2004 Soil microbial metabolism and nutrient status in a Mediterranean area as affected by plant cover. Soil Biology and Biochemistry 36: 1719-1729.

Sanchez, P. A.

1976 Properties and management of soils in the tropics. Wiley, New York. Science.618.

Singh, A. N., A. S. Raghubanshi, and J. S. Singh.

2004 Comparative performance and restoration potential of two Albizia species planted on mine spoil in a dry tropical region, India. Ecological Engineering 22: 123-140.

Tolentino, E.L.

2008 Restoration of Philippine native forest by smallholder tree farmers. In:Snelder DJ, Lasco RD (eds) Smallholder tree growing for rural development and environmental services. Springer, Netherlands, pp 319 $-346$.

Tucker, N.I.J.

2000 Wildlife colonisation on restored tropical lands: what can it do, how can we hasten it and what can we expect? In: Elliot, S., J. Kerby, D. Blakesley, K. Hardwick, K. Woods, V. Anusarnsunthorn (Eds.), Forest Restoration for Wildlife Conservation, Chiang Mai University, pp 278295.

Tucker, N.I.J., and T.M. Murphy.

1997 The effects of ecological rehabilitation on vegetation recruitment: some observation from the Wet Tropics of North Queensland. Journal of Forest Ecology and Management 99: 133 - 152. 

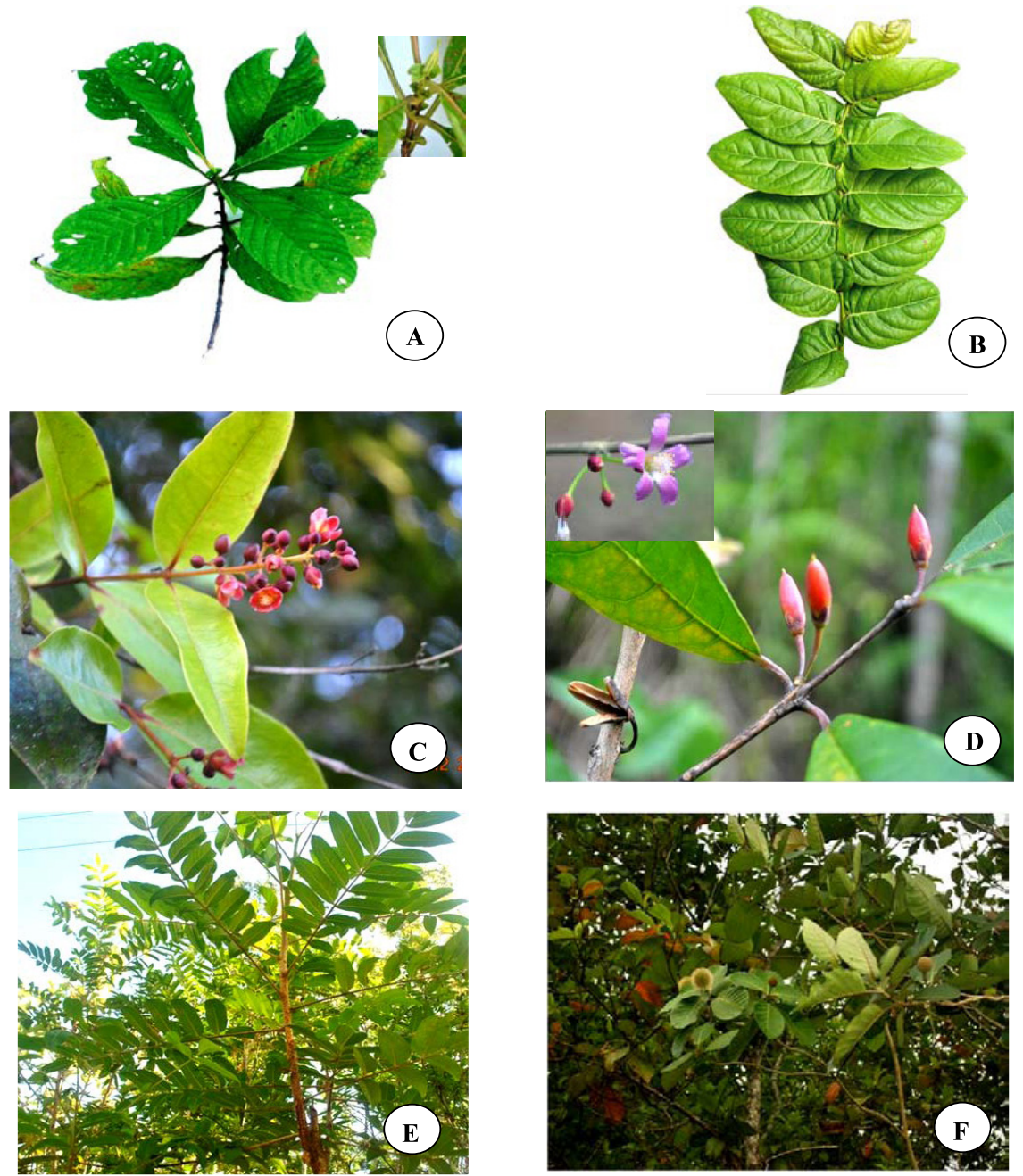

Plate 1. Some of the potential species found in Mt. Musuan, Bukidnon, Philippines

(A. Wendlandia luzoniensis; B. Phyllanthus albus; C. Cratoxylum sumatranum; D. Cratoxylum formosum; E. Rhus taitensis; F. Neonauclea formicaria). 

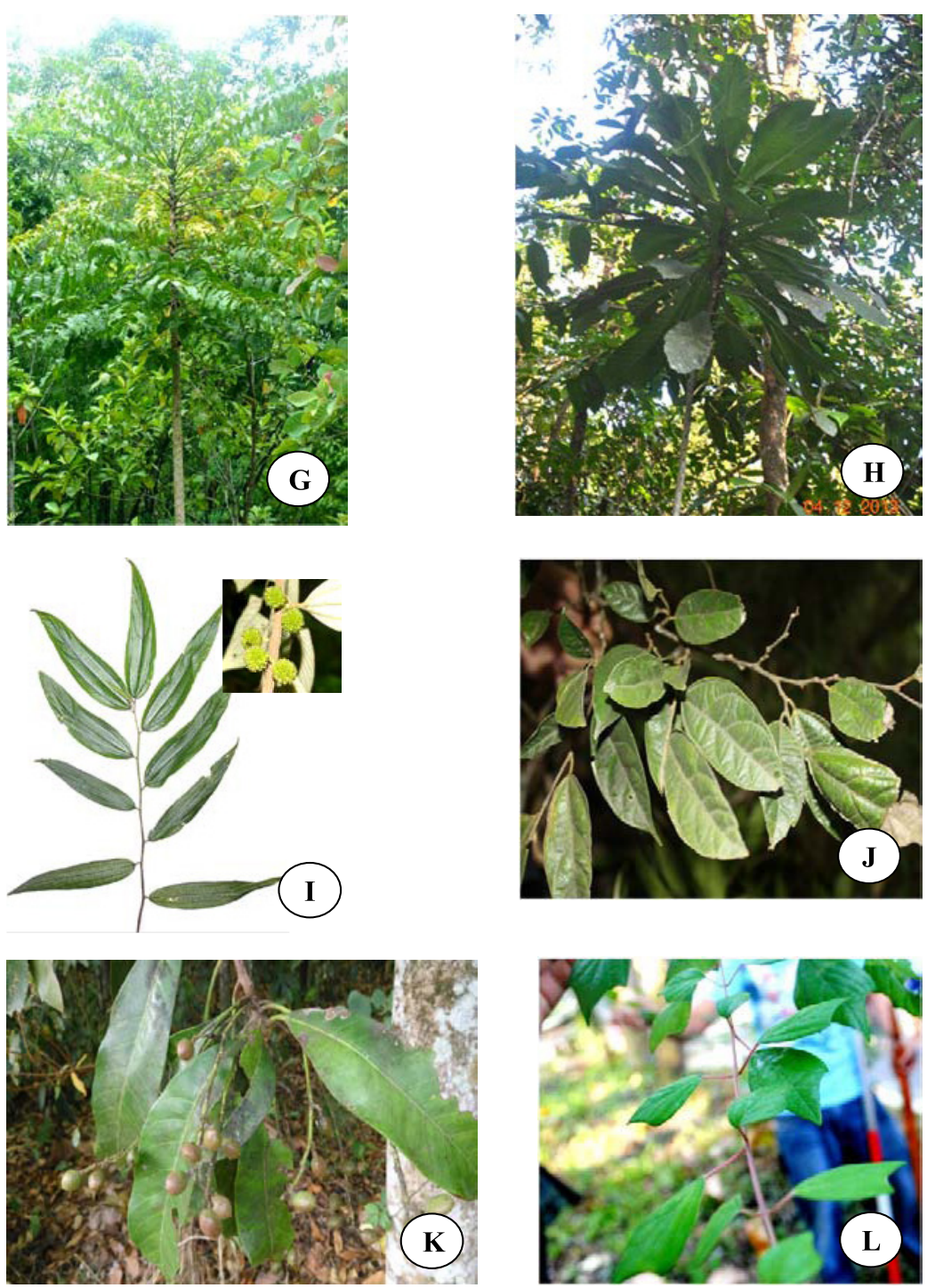

Plate 2. Some of the potential species found in Mt. Musuan, Bukidnon, Philippines

(G.Polyscias nodosa; H. Ficus pseudopalma; I. Leucosyke capitellata; J. Ficus ampelas; K. Buchanania arborescens; L. Gmelina elliptica). 